\title{
Intracircuit Nonacquiescence and the Breakdown of the Rule of Law: A Response to Estreicher and Revesz
}

\author{
Matthew Diller† and Nancy Morawetz††
}

Over the past decade, administrative agency nonacquiescence-the refusal of an administrative agency to apply the law of the reviewing court $^{1}$ - has been roundly condemned by the courts. ${ }^{2}$ In requiring agencies

† Staff Attorney, Civil Appeals and Law Reform Unit, The Legal Aid Society, New York.

H Assistant Professor of Clinical Law, New York University School of Law. The authors gratefully acknowledge the comments of Jane Booth, Rochelle Dreyfuss, Katherine Kennedy, Burt Neuborne, Michael Rips, Lawrence Sager, and David Udell; the research assistance of Karen Cole and Heidi Liss; and the financial support of the Filomen D'Agostino and Max E. Greenberg Research Fund of New York University School of Law. We are among the counsel for the plaintiff class in Stieberger v. Sullivan, No. 84 Civ. 1302 (S.D.N.Y. filed Feb. 24, 1984), a class action challenging nonacquiescence by the Social Security Administration. Portions of this article are drawn from comments we submitted on behalf of the Stieberger class to the Administrative Conference of the United States in response to the proposals of Professors Estreicher and Revesz. See Estreicher \& Revesz, Nonacquiescence by Federal Administrative Agencies, 98 YALE L.J. 679 n.H (1989). The views expressed in this article are our own and do not represent the position of The Legal Aid Society or the Stieberger class.

1. The issue of nonacquiescence is raised most clearly by the conduct of the Sacial Security Administration (SSA). SSA has been essentially unique in its vigorous defense of the right to nonacquiesce within a circuit. Other agencies that are certain which circuit will review their decisions generally practice intracircuit acquiescence while pursuing their right to litigate an issue in other circuits. See Estreicher \& Revesz, supra note H, at 743 n.308 (1989); see, e.g., Anselmo, Int., Dec. 3105, Bureau of Immigration Appeals, May 11, 1989, reprinted in INTERPRETER ReleAses (May 26,1989 ) (rejecting policy of intracircuit nonacquiescence in deportation proceedings).

Based on their survey of fifty administrative agencies, Estreicher and Revesz categorize only four agencies other than SSA as practicing intracircuit nonacquiescence: the Federal Labor Relations Authority (FLRA), the Federal Trade Commission (FTC), the Merit Systems Protection Board (MSPB), and the Internal Revenue Service (IRS). Estreicher \& Revesz, supra note + , at 714 , 717-18. The precise policy of the largest of these agencies, the IRS, is somewhat unclear. Compare Letter from James K. Keightly, Associate Chief Counsel (Litigation), Department of the Treasury, to Mary Candace Fowler, Administrative Conference of the United States (May 9, 1988) ("Even in those limited circumstances where the Service states its disagreement with a decision of a court of appeals, its well known policy is to give venue effect to those decisions both administratively and in litigation until any conflict among the circuits is resolved.") (on file with authors) with Letter from Daniel F. Folzenlogen, Special Appellate Counsel, Department of the Treasury, to Mary Candace Fowler, Administrative Conference of the United States (July 26, 1988) ("[The] IRS rarely engages in relitigation of issues within a committed circuit unless it is seeking clarification of the ruling of that circuit; it is asking the committed circuit to reconsider its holding in light of the decisions of other circuit courts of appeals; or it believes that Supreme Court review will or might result.") (on file with authors). Of the other three agencies, only the MSPB operates in a system of venue certainty. See 5 U.S.C. $\$ 7123$ (a) (1988) (venue for decisions of FLRA); 15 U.S.C. $\$ 45$ (c) (1988) (venue for adjudicatory decisions of FTC). The MSPB has only recently adopted a policy of nonacquiescence. Estreicher \& Reves2, supra note $\#$, at 718.

2. See Hyatt v. Heckler, 807 F.2d 376, 379 (4th Cir. 1986), cert. denied, 484 U.S. 820 (1987); Beverly Enters. v. NLRB, 727 F.2d 591, 593 (6th Cir. 1984); Douglas v. Schweiker, 734 F.2d 399, 
to comply with circuit precedent, the courts have drawn a sharp line between the authority of the government to pursue litigation in circuits that have not yet ruled on an issue and its obligation to accept the settled law of circuits that have ruled against the government. ${ }^{3}$ The proposition that the government should not litigate cases that are frivolous under circuit law is so accepted by the courts and practitioners that, in 1984, two United States Attorneys announced that they would not defend cases in which a government agency had violated circuit precedent."

In their recent article, Nonacquiescence by Federal Administrative Agencies, ${ }^{5}$ Professors Samuel Estreicher and Richard Revesz argue that nonacquiescence within a circuit may be legitimate, even when the law of the circuit is clearly settled. ${ }^{6}$ They argue that nonacquiescence in a circuit's case law is permissible so long as the agency is reasonably seeking to vindicate its position in the courts and is forwarding a position that is not "so bereft of support in available legal materials that it is unlikely to be accepted by any other court of appeals." In their view, not only is the agency under no obligation to follow settled circuit law in such circumstances, but it should also be insulated from injunctive relief that requires prospective compliance with the law of the circuit. ${ }^{8}$

To support their standard, Estreicher and Revesz present an analysis of

400 (8th Cir. 1984); Lopez v. Heckler, 713 F.2d 1432 (9th Cir. 1983), adhered to, 725 F.2d 1489, 1496-97, 1500-01 (9th Cir.), vacated on other grounds, 469 U.S. 1082 (1984); PPG Indus. v. NLRB, 671 F.2d 817, 822-23 (4th Cir. 1982); Ithaca College v. NLRB, 623 F.2d 224, 228 (2d Cir.), cert. denied, 449 U.S. 975 (1980); Mary Thompson Hosp., Inc. v. NLRB, 621 F.2d 858, 864 (7th Cir. 1980); Allegheny Gen. Hosp. v. NLRB, 608 F.2d 965, 969-70 (3d Cir. 1979); Federal-Mogul Corp. v. NLRB, 566 F.2d 1245, 1252 (5th Cir. 1978); Stieberger v. Heckler, 615 F. Supp. 1315, 1331-32 (S.D.N.Y. 1985), vacated on other grounds, 801 F.2d 29 (2d Cir. 1986). But see Yellow Taxi Co. v. NLRB, 721 F.2d 366, 384-85 (D.C. Cir. 1983) (Wright, J. concurring). One court has referred to an agency's failure to cite circuit law as a "symbolic bookburning difficult to ascribe to oversight." NLRB v. Eastern Smelting \& Ref. Corp., 598 F.2d 666, 670 n.7 (1st Cir. 1979).

3. See, e.g., Stieberger v. Heckler, 615 F. Supp. at 1359.

4. U.S. Official Curbs Disability Actions, N.Y. Times, Sept. 23, 1984, at 54, col. 4; see Stieberger, 615 F. Supp. at 1354 (quoting statement of United States Attorney for Southern District of New York).

5. Estreicher \& Revesz, supra note + , at 679.

6. Estreicher and Revesz would permit nonacquiescence in the face of repetitive rulings from a circuit rejecting the agency's position. Their model only asks whether there is a chance of convincing another circuit of the agency's position, and whether the agency is pursuing a reasonably vigorous litigation strategy. Id. at 753 .

7. Id. They would also require that the issue be one over which the agency has a responsibility for uniform administration. Id.

8. Estreicher and Revesz also address intercircuit nonacquiescence and nonacquiescence in the presence of venue uncertainty. Intercircuit nonacquiescence has not been very controversial and has not led to criticism from the courts. See Judicial Review of Agency Action: HHS Policy of Nonacquiescence: Oversight Hearing Before the Subcomm. on Administrative Law and Governmental Relations of the House Comm. on the Judiciary, 99th Cong., 1st Sess. 133 (1985) (statement of Professor Lea Brilmayer). As they discuss in their article, nonacquiescence in the face of venue uncertainty raises different questions from intracircuit nonacquiescence. See Estreicher \& Revesz, supra note H, at 741-43; Note, Administrative Agency Intracircuit Nonacquiescence, 85 CoLum. L. REv. 582, 604-05 (1985). Most agencies other than SSA that have been criticized for engaging in nonacquiescence have the defense that more than one court has venue over their decisions. Estreicher \& Revesz, supra note $\mathrm{H}$, at $710-12$. 
the costs and benefits of nonacquiescence. The principal benefit they associate with nonacquiescence is the development of a uniform national standard through intercircuit dialogue. They suggest that intracircuit nonacquiescence can foster intercircuit dialogue through the continual reconsideration by circuit courts of their precedent. During this process, Estreicher and Revesz would allow an agency to continue to apply its own rules until the judicial system as a whole has rendered a uniform national judgment. Although they recognize that nonacquiescence imposes costs, they argue that an analysis of costs and benefits will always justify some measure of intracircuit nonacquiescence. ${ }^{2}$ They further maintain that Congress has authorized agencies to nonacquiesce through general statutory provisions pertaining to uniform administration of statutes, and that there is no constitutional bar to their proposed standard for intracircuit nonacquiescence. ${ }^{10}$

This Comment critiques Estreicher and Revesz' underlying assumptions about our legal system and their proposed standard for permissible nonacquiescence. We argue that their proposal upsets the balance between agencies and courts by rendering the judiciary essentially powerless to enforce congressional limitations on agency conduct for long periods of time. Part I discusses Estreicher and Revesz' central premise that circuit court precedent is so tentative and malleable that it is not entitled to authoritative force. Part II disputes their assessment of the costs and benefits of nonacquiescence, and shows that their analysis of the role of the circuit courts leads them to overstate the benefits of nonacquiescence while underestimating the resulting systemic inequalities. Part III builds on this analysis to show that there is no basis for the core assumption of Estreicher and Revesz' legal analysis: that nonacquiescence is implicit in the "congressional choice of administrative government."11 Finally, Part IV argues that under the existing structure of the judicial branch, their proposed standard encourages agencies to engage in conduct that violates separation of powers as well as due process and equal protection principles.

\section{The Role of Circuit Court Precedent in Achieving Stability and Gonsistency in the Application of Federal LAWS}

An essential function of a judicial system is to maintain the rule of law. Continuity between legal standards as expressed in judicial decisions and legal standards as observed outside the courts is a central aspect of the

9. Estreicher \& Revesz, supra note + , at 751-53. In particular, Estreicher and Revesz state that the cost-benefit calculus always permits "interim" nonacquiescence as to decisions affecting public benefit programs, irrespective of the consequences for the program's intended beneficiaries. They would limit only the duration of the agency's nonacquiescence. Id. at 757 .

10. Id. at 723-35.

11. Id. at 729 . 
rule of law. This continuity protects the judiciary from being overwhelmed by individual cases, provides for equality of treatment that is not dependent on access to the courts, and enables parties to order their affairs. Absent an ability to establish a rule of law, a judicial system becomes solely a resolver of individual disputes for those who pursue litigation, rather than an expositor of norms.

The central premise of Estreicher and Revesz' article is that our judicial system should be treated as incapable of establishing a rule of law in cases involving Federal agencies unless and until there is percolation of issues throughout the courts of appeals and resolution by the Supreme Court or Congress. Prior to such a nationwide resolution of an issue, they treat the law as established by the circuit courts as merely tentative statements by courts that lack authority to maintain a rule of law within their jurisdictions. They therefore allow agencies to continue to apply rules as though there were no judicial declaration of invalidity, so long as there is a possibility that the agency will eventually convince another circuit of the correctness of the agency's position. Indeed, Estreicher and Revesz go so far as to state that the lower courts should not enforce their declarations through injunctive relief even in a properly certified class action.

Estreicher and Revesz offer two justifications for their view of circuit law. First, they assume that circuit courts may be expected to reconsider their prior holdings whenever an agency position could be accepted by another court. ${ }^{12}$ Thus, they presume that repetitive litigation will contribute to national law development by leading the circuits to revise their precedents until they are in harmony. Second, Estreicher and Revesz see the possibility that a later Supreme Court decision will change the governing Federal law as depriving circuit court decisions of authoritative force, no matter how many times the circuit has revisited an issue and adhered to its precedent. ${ }^{13}$

Estreicher and Revesz' view of circuit court precedent is inconsistent with the central role assigned to these courts in the Federal judicial system. Although they correctly note that one function of circuit courts is to participate in the process of national law development, they would have this role triumph over the circuit courts' essential function of providing a measure of judicial repose within each regional circuit. Neither of their arguments for viewing circuit courts as lacking power to preserve the rule of law squares with the standards that our judicial system has adopted to

12. Estreicher and Revesz advance no argument for why courts of appeals should routinely reassess their decisions in the absence of contrary rulings in other circuits. See id. at 727 (court of appeals expected to be open to reconsidering prior rulings in light of developments in other circuits); $i d$. at 746 (possibility of reconsideration extends to cases where first panel did not fully consider issues). However, they would permit nonacquiescence even where no other court of appeals has addressed the issue or where no split in the circuits has developed. Thus, they treat the possibility of a split in the circuits as having the same consequence as an actual split.

13. Id. at 724-28. 
determine the binding effect of judicial decisions. These standards are both an integral part of our judicial branch as currently structured and are necessary to the preservation of the rule of law. They have full force in Federal agency cases, where the treatment of circuit law as merely a tentative statement of what the law might be would overwhelm the judiciary.

The judicial branch is structured to ensure uniformity and stability of legal standards within each regional circuit while permitting disuniformity among the circuits. The circuit system serves to allocate the judicial power among manageable units that can preserve the rule of law within their jurisdictions through adherence to stare decisis. ${ }^{14}$ Intercircuit stare decisis, however, is not necessary to the maintenance of the rule of law. As long as parties can discern which circuit law applies to any given conduct, the parties can shape their action to conform to legal standards. Furthermore, permitting circuits to independently examine issues contributes to resolution of important legal questions on a national basis. Accordingly, each circuit remains completely free to accept or reject the reasoning of other courts of appeals. ${ }^{16}$ This mixture of uniformity and diversity strikes a balance that permits legal issues to receive independent examination by a number of courts, ${ }^{16}$ while at the same time maintaining a unitary rule of law in any given geographic location.

The rules governing circuit reconsideration of precedent are set forth both in the local rules of courts ${ }^{17}$ and in Rule 35 of the Federal Rules of Appellate Procedure. Together, these rules require panels to follow prior panels within their circuits and limit reconsideration of precedent to the en banc process, which may be resorted to only in specified circumstances. ${ }^{18}$ Local rules requiring panels to abide by the decisions of other

14. See infra pp. 807-09.

15. See J. Moore, 1B Moore's Federal Practice fI 0.402(1) (1988). Similarly, district courts are not bound to follow decisions of other district courts or of courts of appeals for other circuits. Id.

16. See Wallace, The Nature and Extent of Intercircuit Conflicts: $A$ Solution Needed for a Mountain or a Molehill?, 71 CALIF. L. REv. 913, 929-31 (1983).

17. For decisions setting forth the rules of the circuits, see, e.g., Humane Soc'y of United States v. EPA., 790 F.2d 106, 110 n.32 (D.C. Cir. 1986); Jusino v. Zayas, 875 F.2d 986, 993 (1st Cir. 1989); Kremer v. Chemical Constr. Corp., 623 F.2d 786, 788 (2d Cir. 1980), affd, 456 U.S. 461 (1982); United States v. Inmon, 594 F.2d 352, 354 (3d Cir.), cert. denied, 444 U.S. 859 (1979); Willey v. Coiner, 464 F.2d 525, 526 (4th Cir. 1972); Umphlet v. Connick, 815 F.2d 1061, 1063 (5th Cir. 1987); Salmi v. Secretary of HHS, 774 F.2d 685, 689 (6th Cir. 1985); Woodard v. Sargent, 806 F.2d 153, 156 (8th Cir. 1986); United States v. Washington, 872 F.2d 874, 880 (9th Cir. 1989); Plastic Container Corp. v. Continental Plastics of Okla., 708 F.2d 1554, 1559 (10th Cir. 1983); Sherry Mfg. Co. v. Towel King of Fla., Inc., 822 F.2d 1031, 1034 n.3 (11th Cir. 1987); Mother's Restaurant, Inc. v. Mama's Pizza, Inc., 723 F.2d 1566, 1573 (Fed. Cir. 1983). The Seventh Circuit has an internal rule requiring that decisions overturning precedent be circulated to the full court. See United States v. Frederick, 835 F.2d 1211, 1214 n.10 (7th Cir. 1987).

18. In their Reply, Estreicher and Revesz place great weight on the practice, adopted in the Seventh Circuit and occasionally used by other courts, of departing from past precedent through a quasi-en banc process of circulating decisions to all active judges on the court prior to publication. Estreicher \& Revesz, The Uneasy Case Against Intracircuit Nonacquiescence: A Reply, 99 YALE L.J. $831,837-38$ (1990). Our argument is not, however, that the en banc process is too cumbersome to permit routine reassessment of precedent, but instead that the rules are structured to make departures from prior decisions unusual events requiring the attention of the full court. The use of quasi-en banc 
panels were put into place to prevent inconsistencies within circuits that were forcing the circuits into large numbers of en banc hearings. ${ }^{10}$ They reflect traditional principles of stare decisis that hold that judicial decisions create rules binding on the same court and lower courts in similar cases that may arise. ${ }^{20}$ Pursuant to these rules, panels abide by the law of the circuit even where other circuits have adopted contrary views. ${ }^{21}$

Rule 35 complements these local rules by providing for hearings en banc in situations where an inconsistency in the law of the circuit develops or where there is a particularly important issue to be reviewed. Notably, disagreement by another circuit is not a basis for reconsideration of precedent under Rule 35 unless the issue is of "exceptional importance." 22 Even when an issue is of such importance, nothing in Rule 35 mandates that the circuit return to consider the issue. Altogether, the evidence shows that very few cases receive en banc consideration. Over the last decade, 99.5 percent of all court of appeals decisions have been rendered without the en banc process. ${ }^{23}$

These rules do not absolutely foreclose a circuit from overturning its

procedures does not detract from this proposition.

19. See Solimine, Ideology and En Banc Review, 67 N.C.L. Rev. 29, 36 (1988).

20. See Allegheny Gen. Hosp. v. NLRB, 608 F.2d 965, 969-70 (3d Cir. 1979). There are of course many proposals for changing these rules. For example, Judge Posner argues that a panel should be free to abandon circuit precedent when another circuit has adopted a contrary rule. See $\mathbf{R}$. Posner, The Federal Courts: CRISIS and Reform 255-56 (1985). The consequences and permissibility of nonacquiescence in our judicial system, however, must be evaluated in terms of the rules that have been established by Congress and the courts. It is these rules of the judicial branch that determine whether nonacquiescence creates impermissible dual standards of law.

21. See, e.g., Salmi v. Secretary of HHS, 774 F.2d 685, 689 (6th Cir. 1985) (court bound by its prior decision despite contrary subsequent holdings of two circuits).

22. FED. R. APP. P. 35. Maintaining consistency in the law of the circuit is the primary purpose of the en banc rule. As the Supreme Court stated in United States v. American-Foreign S.S. Corp., 363 U.S. $685,689-90$ (1960):

The principal utility of determinations by the courts of appeals en banc is to enable the court to maintain its integrity as an institution by making it possible for a majority of its judges always to control and thereby to secure uniformity and continuity in its decisions, while enabling the caurt at the same time to follow the efficient and time-saving procedure of having panels of three judges hear and decide the vast majority of cases as to which no division exists within the court.

(quoting Maris, Hearing and Rehearing Cases In Banc, 14 F.R.D. 91, 96 (1954)). See Western Pac. R.R. Corp. v. Western Pac. R.R. Co., 345 U.S. 247, 270 (1953) (Frankfurter, J., concurring) (dominant concern of en banc rules is to resolve conflicts within circuit).

In contrast, resolution of inconsistencies across circuits is not a central purpose of the en banc procedure and is not specified as a separate ground for en banc consideration. Instead, the underlying issues must meet the general criteria of Rule 35, which requires that issues be of "exceptional importance." For cases refusing to grant en banc consideration despite contrary rulings of other circuits, see, e.g., Uviedo v. Steves Sash \& Door Co., 760 F.2d 87, 88 (5th Cir. 1985), cert. denied, 474 U.S. 1054 (1986) (denying rehearing en banc despite contrary rules in 11 circuits); Harris v. Pernsley, 820 F.2d 592, 611, 612 n.1 (3d Cir.), cert. denied, 484 U.S. 947 (1987) (denying rehearing en banc despite contrary rule in several other circuits).

23. Solimine, supra note 19 , at 46 . In reply, Estreicher and Revesz claim that this statistic is not significant, and that the only evidence that is pertinent is "the percentage of cases in which there is a conflict in the circuits over an issue of 'exceptional importance' that are not reviewed en banc." Estreicher \& Revesz, Reply, supra note 18 , at 837 . However, because they would permit an agency to nonacquiesce even when there is no conflict in the circuits and the issue is not one of "exceptional importance," the low probability that any given decision will be considered en banc is significant. 
past precedent, but they represent a powerful presumption in favor of the continued authoritative force of the circuit's decisions. It is therefore consistent with these rules for a circuit to return to a decision that has been seriously called into question by numerous subsequent decisions or where an issue is otherwise of extraordinary importance. ${ }^{24}$ But these rules plainly do not presume that the mere disagreement by another circuit-let alone the possibility of a disagreement-overcomes the presumptive force of a circuit's holdings. ${ }^{25}$

The division of circuits into panels makes these rules enhancing circuit stability particularly necessary to preservation of the rule of law. By requiring adherence to prior panel decisions, the circuits are able to maintain a degree of consistency within each circuit that would be impossible if each panel were entitled to reject the conclusion of a prior panel. ${ }^{26} \mathrm{~A}$ system in which panels were free to overturn prior panels would allow the law within each circuit to be in constant flux, and would deprive the circuits of their ability to provide clear direction to parties and the lower courts. Rules of stare decisis promote equality of treatment at the lower court level (as well as for those who never seek judicial review) by giving clear guidance as to the rule of law.

The value of maintaining stability in circuit court precedent flows directly from the nature of a hierarchical legal system. To control the volume of cases requiring adjudication, the circuit courts are designed to hear a limited number of cases, with more routine matters decided by the district courts and administrative agencies, and with parties conforming their

24. See Stieberger v. Heckler, 615 F. Supp. at 1359 \& n.31; see, e.g., Barber v. Ponte, 772 F.2d 982, 1000 (1st Cir. 1985) (en banc) (reversing United States v. Butera, 420 F.2d 564 (1st Cir. 1970)). In their Reply, Estreicher and Revesz point to additional circumstances where circuits have reversed themselves. Estreicher \& Revesz, Reply, supra note 18, at 838. We agree that it is appropriate for circuits to revisit obsolete, outmoded cases, see, e.g., United States v. Kasto, 584 F.2d 268 (8th Cir. 1978), cert. denied, 440 U.S. 930 (1979). We also agree that a decision may be reviewed when there has been a pertinent change in the law. See, e.g., Campos v. Lefevre, 825 F.2d 671 (2d Cir. 1987), cert. denied, 108 S. Ct. 1304 (1988). Other scattered instances in which circuits have reversed themselves do not establish that the principles of stare decisis that order our judicial system have been discarded and that all case law may be regarded as suspect at the time it is issued. In light of the radical view Estreicher and Revesz take of the role of stare decisis in our legal system, we believe that it is they who bear the burden of proving empirically that these rules have no meaning in practice.

25. Thus, it is plainly insufficient under rules of stare decisis and Rule 35 to treat a circuit opinion as lacking authoritative force because another circuit previously ruled the other way. Under Estrcicher and Revesz' model, if circuit one rules for the agency and circuit two rules against the agency, the agency is permitted to nonacquiesce within the jurisdiction of circuit two. The fact that circuit one ruled for the agency is proof of the "justifiability" of the agency's position under their test. The agency would be able to nonacquiesce under their standard if it unsuccessfully sought certiorari. Indeed, they might not require the agency to seek certiorari since the conflict would, at that time, be limited to two circuits. See S. Estreicher \& J. Sexton, Redefining the Supreme Court's Role 58 (1986) (offering three-circuit test for granting certiorari to resolve conflict).

26. See Lacy v. Gardino, 791 F.2d 980, 985 (1st Cir.), cert. denied, 479 U.S. 888 (1986) ("Uniformity of decisions within a multipanel circuit can only be achieved by strict adherence to prior circuit precedent, with the error-correcting function reserved to the court sitting en banc."). See generally Kornhauser \& Sager, Unpacking the Court, 96 YALE L.J. 82, 111 (1986). Although it is more difficult for panels to achieve coherence in their decisions, id., the problem is hardly solved by eliminating the consistency that is achieved by having panels follow the rules set forth by prior panels. 
conduct to the rule of law. If the decisions of the circuits were not accorded precedential weight, but were constantly open to question, these courts could be easily overwhelmed by parties raising issues addressed in earlier rulings by the same court. The system simply could not function if precedent were so unstable. ${ }^{27}$

Because of the size of the Federal agency docket subject to review, the stability and consistency created by these rules for achieving judicial repose within each circuit are essential to orderly judicial review of agency action. ${ }^{28}$ Federal agencies process many times the number of cases that are reviewed in Federal court. ${ }^{29}$ When agencies apply rules differently from the courts, agency adjudication becomes simply a hurdle to overcome before obtaining judicial review. The potential for overwhelming the courts with challenges to agency determinations is staggering. ${ }^{30}$ This bur-

27. For this reason, the two newest courts of appeals have adopted the precedent of their predecessor courts and limited reconsideration of precedent to the en banc process. See South Corp. v. United States, 690 F.2d 1368, 1370 (Fed. Cir. 1982) ("To proceed without precedent, deciding each legal principle anew, would for too long deprive the bar and the public of the stability and predictability essential to the effort of a free society to live under a rule of law."); Bonner v. City of Prichard, 661 F.2d 1206, 1211 (11th Gir. 1981) ("Theoretically this court could decide to proceed with its duties without any precedent, deciding each legal principle anew. . . This court, the trial courts, the bar and the public are entitled to a better result than to be cast adrift among the differing precedents of other jurisdictions, required to examine afresh every legal principle.").

In their Reply to this Comment, Estreicher and Revesz suggest that we view the circuits as independent "fiefdoms" that do not listen to each other. Estreicher \& Revesz, Reply, supra note 18, at 832. We do not argue, however, that the courts of appeals should ignore each other, nor do we deny that circuit courts are part of a single federal system. In fact, to the extent that a circuit court decision is accorded deference in other circuits, the possibility of a later split in the circuits diminishes and the asserted benefits of nonacquiescence become more tenuous. See id. at 834, n.18.

28. Although the Supreme Court's decision in United States v. Mendoza, 464 U.S. 154 (1984), protects the government from non-mutual offensive collateral estoppel, it does not authorize any general exemption from the rules of precedent for the United States. See Estreicher \& Revesz, supra note H, at 684-86; Schwartz, Nonacquiescence, Crowell v. Benson and Administrative Adjudication, 77 GEO. L.J. 1815, 1875-81 (1989). Indeed, Justice White's concurrence in United States v. Stauffer Chemical Co., 464 U.S. 165 (1984), recognizes the powerful role of the law of the circuit in determining the law that should be applied. Id. at 177 (White, J., concurring) (law of circuit overcomes doctrine of mutual collateral estoppel). Application of rules of stare decisis to a Federal agency is particularly reasonable because the agency was party to the case determining the precedent, and had an opportunity to bring relevant arguments to the panel's attention, to petition for rehearing, and to suggest en banc review.

29. Manageability of the Federal caseload for review of agency action depends on a system that avoids reversible error on the part of agency adjudicators. The Federal government processes massive numbers of cases at the administrative agency level. See Strauss, One Hundred Fifty Cases Per Year: Some Implications of the Supreme Court's Limited Resources for Judicial Review of Agency Action, 87 CoLUM. L. REv. 1093 (1987) (number of filings potentially requiring administrative hearings in 1983 was $30 \%$ greater than total number of actions filed in district court). The judicial system would be overwhelmed if all of these cases were adjudicated in conflict with circuit standards. Currently, only a fraction of these cases reach the Federal courts. Id. at 1099 n.28 (citing literature on Federal court workload).

30. For example, in fiscal year 1987 administrative law judges adjudicated over 230,000 claims for Social Security and Supplemental Security Income benefits. Comm. ON Ways and Means, Background Material and Data on Programs Within the Jurisdiction of the Comm. ON Ways and Means, 100th Cong., 2d Sess. 50 (1988). The burden of reviewing the vast numbers of decisions by Federal agencies is currently mitigated by judicial exercise of injunctive powers, and by the widespread adherence of many agencies, such as the Internal Revenue Service and the Immigration and Naturalization Service, to circuit court precedent. See supra note 1. 
den would be even greater if the courts were expected constantly to reconsider their precedents either by abandoning prior panel rulings or through the en banc process.

It may be true that circuits do not always achieve the stability of intracircuit law that our legal system envisions, ${ }^{32}$ but the rules are clearly written to achieve such uniformity. Where the circuits fall short of this goal, the resulting disuniformity is recognized as a crisis requiring reform. For example, at the time Congress decided to divide the Fifth Circuit, that circuit was having substantial difficulty retaining consistency in its decisions and, as a result, was burdened by the administrative cost and delay of numerous en banc petitions. As the House report stated, the circuit was divided to provide a judicial structure "capable of meeting the clear mandates of our judicial system - the rendering of consistent, expeditious, fair and inexpensive justice."32

Apart from these structural reasons why circuit court decisions serve as definitive statements of law within their jurisdictions, there are many practical reasons why Estreicher and Revesz' vision of the role of circuit law is unrealistic. They essentially view case law as setting forth distinct issues that are developed in a large number of circuits and ultimately resolved by a conflict resolver, such as the Supreme Court. Although this view of the law may make sense from the perspective of issues the Supreme Court has actually decided, it mischaracterizes the nature of the judicial landscape on statutory issues. Many statutory issues are too shortlived to be passed on by all circuits and to warrant Supreme Court review. ${ }^{33}$ Other issues may arise too infrequently to be passed on by a large number of circuits. ${ }^{34}$ Some issues are not significant enough to lead to

31. See Strauss, supra note 29, at 1106 n.53 (assumption that en banc process ensures intracircuit uniformity may be "heroic").

32. H.R. ReP. No. 1390 , 96 th Cong., 2d Sess. 1, reprinted in 1980 U.S. Code Cong. \& Admin. NEWS 4236, 4237.

33. Many statutory provisions expire by their own terms after a specified period of time. The Supreme Court is likely to view these issues as lacking sufficient significance to warrant high court review. For example, the statutory standard for evaluations of pain in the Social Security disability program, enacted in 1984, had a sunset date of January 1, 1987. See 42 U.S.C. $\S 423$ (d)(5)(A) (1982 \& Supp. V 1987). The interpretation of this provision is therefore an unlikely candidate for Supreme Court review. The proper interpretation of the provision is nonetheless extremely important to disability cases and has been a subject of much litigation. See, e.g., Duncan v. Secretary of HHS, 801 F.2d 847 (6th Cir. 1986); Green v. Schweiker, 749 F.2d 1066 (3d Cir. 1984); Polaski v. Heckler, 751 F.2d 943, 950 (8th Cir. 1984), remanded on other grounds sub nom. Bowen v. Polaski, 476 U.S. 1167, adhered to, 804 F.2d 456 (8th Cir. 1986), cert. denied, 482 U.S. 927 (1987).

34. There are many statutory issues that arise rarely in circuit case law, even though this case law sets standards that affect other cases. For example, the issue in Smith v. Heckler, 820 F.2d 1093 (9th Cir. 1987), was whether an illegitimate, posthumously born child could receive Social Security survivors' benefits if the deceased wage earner provided support to the surviving parent but had no intention of supporting the unborn child. Although SSA undoubtedly processes applications of similarly situated persons, such eligibility issues are not often litigated. 
higher review..$^{35}$ With respect to many issues, the circuits will ultimately agree with each other..$^{36}$

Of course, when a significant conflict develops, the Supreme Court will sometimes intervene. Estreicher and Revesz, however, significantly overstate the role of Supreme Court review in resolving statutory issues. They view the potential for intercircuit conflict followed by Supreme Court resolution to be so great as to render decisions by the courts of appeals mere points along the path to the high court. ${ }^{37}$ While the Supreme Court remains, along with Congress, the arbiter of last resort on statutory issues, its decisional capacity is small compared to the large number of statutory matters addressed by the courts of appeals. ${ }^{38}$

Even if the Supreme Court eventually resolves an issue decided by the court of appeals, there are numerous reasons to treat the declarations of the courts of appeals as authoritative, pending a determination by the Supreme Court. The Supreme Court frequently addresses narrowly

35. See R. Stern, E. Gressman \& S. Shapiro, Supreme Court Practice $\S 4.4$ (6th ed. 1986) (issues not of sufficient general importance may be denied review despite conflict among circuits). For example, there is an outstanding conflict between the Federal Circuit and the District of Columbia, Third, and Fifth Circuits over the standard for review of denials of certain pay increases to Federal workers. Compare Romane v. Defense Contract Audit Agency, 760 F.2d 1286 (Fed. Cir. 1985) (substantial evidence standard) with White v. Department of the Army, 720 F.2d 209 (D.C. Cir. 1983) (preponderance of the evidence standard) and Stankis v. EPA, 713 F.2d 1181 (5th Cir. 1983) (same) and Schramm v. HHS, 682 F.2d 85 (3d Cir. 1982) (same).

36. For example, the courts ultimately reached agreement on the question of the appropriate standard for terminating disability benefits. See infra pp. 826-28. As Estreicher and Revesz recognize in their Reply, principles of deference to coordinate courts serve to reduce conflicts among the circuits. See Estreicher \& Revesz, Reply, supra note 18, at 834 n.18.

37. In their article, Estreicher and Revesz acknowledge that in practice Supreme Court review is frequently unavailable. Estreicher \& Revesz, supra note $H$, at 744 . Nonetheless, their analysis depends upon sufficient availability of Supreme Court review to render decisions by courts of appeals inherently unstable unless there is a clear consensus among circuits.

38. See Strauss, supra note 29, at 1099-1100 \& n.28. Many commentators have observed that these limitations on the workload of the Supreme Court prevent the Court from acting in a timely manner to resolve all conflicts. See, e.g., R. Posner, The Federal Courts 162 (1985); Baker \& McFarland, The Need for a New National Court, 100 HARv. L. Rev. 1400, 1406-07 (1987).

Relying on a recent study of certiorari decisions in the 1982 term, Estreicher and Revesz state that the Court has the capacity to intervene in all important conflicts. Estreicher \& Revesz, supra note H, at $752 \mathrm{n} .331$. The Supreme Court study, however, is directed to a different question from that raised by intracircuit nonacquiescence. The study asks whether there is an intolerable level of conflict over "important" questions. It does not ask whether the courts conflict over the proper interpretation of all issues of statutory and regulatory law. Circuit court decisions that create conflicts that are "tolerable" from the standpoint of the Supreme Court are the least likely to be affected by subsequent Supreme Court action. See generally Sturley, Observations on the Supreme Court's Certiorari Jurisdiction in Intercircuit Conflict Cases, 67 TEx. L. REv. 1251, 1257-60 (1989) (intercircuit conflicts are tolerable for multijurisdictional actors if they can predict what law will apply to any given transaction); Posner, supra, at 163 (Federal government can adjust conduct across jurisdictions). The Supreme Court study is also limited to issues brought to the Court's attention. In their Reply, Estreicher and Revesz suggest that nothing short of incompetence among practitioners could explain the existence of conflicts nat included in the study. Estreicher \& Revesz, Reply, at 836 n.29. There are many reasons, however, why practitioners may not seek certiorari. In addition to the factors that may indicate a low likelihood that the Court will grant certiorari, see supra notes 33-38 and accompanying text, a simple weighing of costs of further litigation and the potential benefits of Supreme Court review may lead a party to abandon a claim after the court of appeals level. Baker \& McFarland, supra, at 1406-07; cf. G. Casper \& R. Posner, The Workload of the Supreme Court 31, 61 (1976) (low probability of review decreases incentives to file for certiorari). 
framed questions that leave many matters unresolved. ${ }^{39}$ By issuing narrowly tailored rulings, the Supreme Court can alter the debate on statutory issues rather than finally resolving the matters in dispute. Furthermore, the Supreme Court may sustain the courts of appeals that ruled against an agency. Lastly, the interval between a court of appeals decision and a subsequent Supreme Court decision on the same issue is often measured in years. ${ }^{10}$ During this period, the court of appeals decision remains the last word within the circuit in which it was rendered.

Altogether, because of the likelihood that the Federal courts will agree as to matters of statutory interpretation, the rules curtailing revision of precedent, and limitations on Supreme Court review, our legal system treats the law of the circuit as authoritative until it is overturned. By modeling their analysis on three contingencies-that the courts of appeals might come into conflict whenever the agency's position is not "bereft of support," that any such conflict could lead to reconsideration by the first court or to Supreme Court review, and that such reconsideration or review will overturn a circuit court decision adverse to the agency-Estreicher and Revesz treat the exceptional situation as the norm and vastly understate the degree to which our judicial system depends on the circuit courts to provide order and stability in the administration of the law.

39. The Supreme Court's decision in Heckler v. Day, 467 U.S. 104 (1984), illustrates how Supreme Court decisions may leave many issues unresolved. In Day the Court held that courts may not impose class-wide nonstatutory deadlines on the adjudication of claims for disability benefits to remedy unreasonable delays by SSA. The decision, however, left open all other questions concerning individual and class relief for unreasonable delays, 467 U.S. at $119 \mathrm{n} .33$, and the circuits have divided over the availability of other forms of class-wide relief. Compare Barnett v. Bowen, 794 F.2d 17 (2d Cir. 1986) (holding class-wide notice relief to be appropriate) with Crosby v. SSA, 796 F.2d 576 (1st Cir. 1986) (rejecting Barnett).

Another example is the Supreme Court's narrow decision in Heckler v. Campbell, 461 U.S. 458 (1983), upholding regulations for determining whether a person who claims disability can adjust to other work in the national economy. Although the Court upheld the validity of the regulations, it reserved many issues regarding their application. For example, it did not rule on the validity of the guidelines for determining whether a person's age renders him or her unable to make a vocational adjustment to other work. Id. at 464 n.8. This issue had itself divided the circuits, compare Broz v. Schweiker, 677 F.2d 1351, 1359, 1360 (11th Cir. 1982), vacated, 461 U.S. 952 (1983) with Cummins v. Schweiker, 670 F.2d 81, 83 (7th Cir. 1982); and remains unresolved, compare Reeves v. Heckler, 734 F.2d 519 (11th Cir. 1984) (Secretary cannot apply vocational guidelines where claimant has presented substantial credible evidence that claimant's ability to adapt to new work environment is less than level presumed by guidelines) with Underwood v. Bowen, 828 F.2d 1081, 1083 n.1 (5th Cir. 1987) (declining to rule on issue decided by Eleventh Circuit in Reeves). Complete resolution of these issues could last many years past the useful life of the regulations themselves. Because the regulations reflect fact findings about jobs in the economy made in 1980, they will probably become obsolete before all issues about their proper application are resolved.

40. See, e.g., United States v. Bartlett, 794 F.2d 1285, 1293 (8th Cir. 1986), cert. denied, 479 U.S. 934 (1986) (noting five year gap between circuit's decision in United States v. Dupris, 612 F.2d 319 (8th Cir. 1979), vacated on other grounds, 446 U.S. 980 (1980), and Solem v. Bartlett, 465 U.S. 463 (1984)); see also Comm'n on Revision of the Federal Court Appellate System, STructure and Internal Procedures: Recommendations for Change 13 (1975) (resolution of conflicts may come after years of uncertainty and confusion). 


\section{The Costs and Benefits of Nonacquiescence}

In light of structural limitations on circuit reconsideration of past precedent, Estreicher and Revesz have greatly overstated the systemic benefits of nonacquiescence while underestimating the devastating costs nonacquiescence may have in practice. Each of the benefits they associate with nonacquiescence is premised on a strong likelihood that circuits will depart from the rules of stare decisis. In fact, only three cost-benefit factors play a significant role: the hardship for those who are denied the benefit of the circuit rule at the administrative level and are unable to seek the judicial review necessary to gain the benefit of the court rule; the financial cost and hardship due to delay imposed on those who manage to appeal to court; and the burden of repetitive litigation, borne by the judiciary. Because the hardship to parties affected by nonacquiescence can only be mitigated through massive repetitive litigation, the overall costs of nonacquiescence can be shifted but will always remain significant.

The three benefits Estreicher and Revesz attribute to nonacquiescence are intercircuit dialogue, uniformity of treatment, and uniformity of administration. ${ }^{41}$ These suggested benefits disappear when one recognizes that stare decisis plays a central role in maintaining the stability of law within the circuits.

As Estreicher and Revesz recognize, agency compliance with circuit law within a circuit does not inhibit the primary form of intercircuit dialogue where circuits consider issues that have been ruled on by other circuits. But they propose that proper "percolation" of issues in the courts of appeals requires that circuit courts reconsider issues that they previously resolved. ${ }^{42}$ The marginal benefits to intercircuit dialogue that Estreicher and Revesz attribute to nonacquiescence depend on such circuit reconsideration being common, if not the norm. ${ }^{43}$ Given the circuit court rules designed to achieve stability of precedent, however, it will be the rare case in which nonacquiescence leads to any additional intercircuit dialogue.44

The stability of circuit law also provides strong reason to doubt that

41. Estreicher \& Revesz, supra note H, at 743-49.

42. It is far from obvious that intracircuit nonacquiescence is necessary for a circuit to reconsider an issue. In addition to the possibility of pursuing a declaratory judgment, an agency can often seek to relitigate an issue in the context of a case where there are issues about the proper application of precedent. See Stieberger v. Heckler, 615 F. Supp. 1315, 1360 \& n.32 (S.D.N.Y. 1985), vacated on other grounds, 801 F.2d 29 (2d Cir. 1986).

43. Much of the discussion of dialogue in Estreicher and Revesz' Reply is devoted to the general value of intercircuit dialogue. Estreicher \& Revesz, Reply, supra note 18, at 833-35. The only issue relevant to intracircuit nonacquiescence, however, is the marginal benefit provided by repetitive litigation in a circuit that has already ruled on a question. Notably, they would allow intracircuit nonacquiescence in order to protect the agency's ability to relitigate even where there has been no subsequent decision by another circuit that creates a conflict.

44. Because courts are so hesitant to abandon their precedents, the danger of a "ratchet effect" operating against an agency is greatly exaggerated. See Estreicher \& Revesz, supra note H, at 739; Estreicher \& Revesz, Reply, supra note 18, at 835. Unfair ratcheting is especially unlikely in light of the high degree of deference courts pay to agencies. 
nonacquiescence enhances uniform application of Federal law. Estreicher and Revesz suggest that requiring administrative adherence to decisions of the courts of appeals within their jurisdictions promotes disuniformity among regions of the country and, in some situations, may even lead to decisions in one jurisdiction having effects in other jurisdictions. Thus, they suggest, an air pollution standard applied in one state will affect a downwind state's air and will affect the relative competitiveness of industry in two states. ${ }^{45}$ At a more general level, they suggest that treating people differently depending on where they live is inherently unfair.

The difficulty with this analysis is that it presumes that nonacquiescence somehow enhances national uniformity. Problems caused by differing regional rules are irrelevant to an analysis of nonacquiescence unless nonacquiescence contributes to uniformity across regions. Only in exceptional circumstances where the circuit will depart from its past precedent is there any possibility that intracircuit nonacquiescence will advance intercircuit uniformity. Nonacquiescence by itself does not lead to uniform application of the law, because in regions where the judicial precedent sets forth standards or procedures that differ from the policy applied by an agency, parties that lose before the agency need only seek judicial review to obtain the benefit of circuit court precedent. Absent barriers to judicial review (such as lack of legal counsel, lack of knowledge that the standards applied by the judiciary differ from those of the agency, or a judgment that the amount at issue does not justify the cost of litigation), all disappointed parties affected by nonacquiescence can be expected to vindicate their rights in court. So long as the circuit court's rule continues to be available to those who live in its region, nonacquiescence only serves to cause gross disuniformity between those who can pursue their appeals and those who cannot. ${ }^{48}$

The third benefit Estreicher and Revesz attribute to nonacquiescence is that it saves the agency the costs of differential administration associated with applying different sets of rules in different parts of the country. Here Estreicher and Revesz focus solely on the costs of following circuit law,

\footnotetext{
45. Estreicher \& Revesz, supra note H, at 747 .

46. When uniform national rules are especially important, Congress can create special courts or venue rules to assure uniformity. For example, when Congress became concerned about disuniformity in the interpretation of patent law and the forum shopping which resulted, it removed appeals in such cases from the jurisdiction of the regional courts of appeals and transferred jurisdiction to the Court of Appeals for the Federal Circuit. Federal Courts Improvement Act of 1982, Pub. L. No. 97-164, 1982 U.S. Code Cong. \& Admin. News (96 Stat.) 25, 38. See S. Rep. No. 275, 97th Cong., 2d Sess. 5, reprinted in 1982 U.S. CODE CONG. \& ADMIN. NEwS 11, 15. In the case of ambient air standards, the example provided by Estreicher and Revesz, Congress assured uniformity by creating exclusive venue in the District of Columbia Circuit. 42 U.S.C. \$ 7607(b)(1) (1982). Disuniformity is generally viewed as only problematic in situations where there is a high possibility of forum shopping or a multi-circuit actor cannot determine how to plan its behavior to comply with the law. See S. EsTREICHER \& J. SEXTON, supra note 25, at 57-58; Sturley, supra note 38, at 1259-60. Where disuniformity is problematic, nonacquiescence is no solution because it creates its own disuniformities. See infra pp. 814-15.
} 
while ignoring administrative savings from adherence to the law that, in all likelihood, would be applied by the reviewing court. Courts are likely to find error in agency decisions that are not made in accordance with circuit law. Because of the deference granted to agencies as fact finders, the outcome on appeal will often be a remand to the agency for application of judicial standards to the case. This is especially likely when the court concludes that there has been an error of law, or that some required procedural rule has not been followed. ${ }^{47}$ As a result, any accurate measure of the administrative costs of nonacquiescence must account for both the costs of differential administration and the costs of conducting additional administrative proceedings to apply the law of the circuit. In many cases, nonacquiescence causes two rounds of administrative proceedings where only one would have been necessary if circuit rules had been applied by the agency in the first instance. If all parties affected by nonacquiescence managed to obtain judicial review, there can be little question that the administrative costs of readjudicating every case where the circuit abides by its prior decisions would exceed those of compliance with case law. ${ }^{48}$

While Estreicher and Revesz inflate the benefits of nonacquiescence, they vastly understate its costs. They identify two costs: distributional consequences for those who do not appeal and increased judicial workload. Each of these repercussions is far more severe than they suggest. ${ }^{49}$

Estreicher and Revesz recognize that nonacquiescence frequently imposes costs on parties who lack the resources or the sophistication to commence litigation to obtain the benefit of judicial precedent. These parties are unable to obtain the benefit of circuit court rules and may suffer serious harms, such as the termination of subsistence benefits or deportation, which would be avoided by application of circuit court precedent. Indeed, even for those who have the resources to obtain judicial review, Estreicher and Revesz recognize that the costs of litigation may result in affected parties deciding not to pursue their right to application of circuit prece-

47. See, e.g., Stone v. Heckler, 752 F.2d 1099, 1106 (5th Gir. 1985) (announcing that court will remand all future cases where agency has applied incorrect legal standard for evaluating disability).

48. There is also good reason to doubt agency protestations about the costs of conveying circuit rules to agency decisionmakers within a particular jurisdiction. Estreicher and Revesz quote counsel for the IRS, the NLRB, and HHS as support for the proposition that there are "high costs" to differential administration. Estreicher \& Revesz, supra note $\#$, at $690-91$ \& nn.40-41, 749 n.323. Some of these costs are simply a product of the fact that the agencies have not organized themselves to facilitate acquiescence. For example, if Congress created venue certainty for the NLRB, as Estreicher and Revesz propose, the NLRB's regional offices could be reorganized along circuit lines. Estreicher \& Revesz, supra note + , at 741-43. Similarly, the problem of updating instructions is one that agencies already face and have established mechanisms to accommodate. SSA, for example, uses various forms of transmittals and program circulars to apprise adjudicators of developments that they want them to follow. Such circulars are often tailored to questions that arise in a particular region. In fact, SSA circulates court decisions that it agrees with as binding Social Security Rulings. The question is not one of mechanisms to convey court decisions, but rather an agency's willingness to do so.

49. Estreicher and Revesz also omit some costs of nonacquiescence borne by the agencies. Nonacquiescence undermines respect for agencies, thereby diminishing voluntary compliance with the law. It further imposes significant litigation costs on the government. See Note, supra note 8, at 603 . 
dent. ${ }^{50}$ As a result, nonacquiescence creates its own disuniformities by making a different set of rules available to those who can litigate and those who cannot. The availability of one set of legal standards for those who seek review and another set for those who are unable to vindicate their rights in court undermines the integrity of administrative government. ${ }^{32}$ Such a dual standard of law is particularly offensive because it is not an incidental by-product of nonacquiescence. Rather, from an agency's standpoint, many benefits of nonacquiescence are directly related to the inability of affected parties to challenge its decisions in court. ${ }^{\mathbf{2}}$

The disparate treatment of the rich and the poor engendered by nonacquiescence is not the only distributional consequence of such a policy. An additional and potentially devastating consequence of nonacquiescence is that those parties before the agency that can and do appeal to court must wait until they have exhausted administrative and judicial proceedings before they can receive the benefit of the circuit's law. The Estreicher and Revesz analysis misses this crucial time dimension.

The hardship caused by having to wait for judicial rules to be applied is perhaps clearest in the Social Security context. ${ }^{53} \mathrm{~A}$ recent study by the General Accounting Office shows that the average length of time between an initial application for Social Security benefits and completion of proceedings following remand is close to four years. ${ }^{54}$ During this time period, many disabled persons are forced to subsist on state public assistance

50. Estreicher \& Revesz, supra note $\dagger$, at 746.

51. Estreicher and Revesz liken the unfairness of applying different standards to parties based solely on their ability to engage in litigation to a system of law in which a litigant "can purchase the rule of law which will govern the disposition of his case and [in which] more favorable rules of law are progressively more expensive." Id. at 750. As Judge Sand explained in Stieberger v. Heckler:

The consequence of [SSA's] non-acquiescence policy is simply this: one set of rules applies to those claimants fortunate enough to procure legal representation, persistent enough to appeal an adverse determination of the various non-acquiescing levels of the agency to a federal court bound to follow the Court of Appeals ruling, and healthy enough to endure this belabored process; a different and adverse rule will govern the rights of those claimants who are unrepresented, insufficiently persistent in their efforts to invoke the benefits of favorable federal judicial rulings, or incapable of doing so. The arbitrariness of such a system is evident simply from its description.

615 F. Supp. 1315, 1362-63 (S.D.N.Y. 1985), vacated on other grounds, 801 F.2d 29 (2d Cir. 1986); see Note, Collateral Estoppel and Nonacquiescence: Precluding Government Relitigation in Pursuit of Litigant Equality, 99 HARv. L. REv. 847, 857-58 (1986).

52. Estreicher and Revesz are more solicitous of the actual costs of relitigation when they discuss Alan Morrison's proposal for "test case" nonacquiescence. In that context, they recognize that the costs of compliance for the party appearing before the agency may be less than the costs of litigation. Estreicher \& Revesz, supra note $\#$, at 746-47.

53. See generally Kubitschek, Social Security Administration Nonacquiescence: The Need For Legislative Curbs on Agency Discretion, 50 U. PITT. L. REv. 399, 408-12 (1989) (discussing harm to Social Security recipients and applicants caused by nonacquiescence). Although Estreicher and Revesz treat the Social Security example as simply one of many contexts for evaluating intracircuit nonacquiescence, SSA is one of very few agencies that actually practices intracircuit nonacquiescence. See supra note 1. Indeed, Estreicher and Revesz devote substantial attention to the SSA experience in their article and use it as a primary example of intracircuit nonacquiescence.

54. U.S. Gen. Accounting Office, Social Security: Selective Face-to-Face Interviews with Disability Claimants Could Reduce Appeals 13 (1989) (Table 1.2). 
programs. ${ }^{55}$ Others are left with no means of subsistence. ${ }^{58}$ The benefits these claimants receive after years of administrative and judicial proceedings can hardly compensate for the loss of the benefits when they were most needed. While waiting for the application of circuit law to their cases, claimants may be deprived of basic necessities such as food, ${ }^{67}$ shelter, ${ }^{68}$ and necessary medical care. ${ }^{59}$ They literally may not survive until the day when benefits are finally granted..$^{80}$

Outside the Social Security context, delay creates cognizable costs, although not as dire. For example, Estreicher and Revesz suggest that the Merit Systems Protection Board engages in some degree of intracircuit nonacquiescence. ${ }^{61}$ In these cases, significant delays in grade increases and reinstatement may affect an individual's career path and ability to obtain

55. Even persons with private pension plans can be forced to turn to public assistance because such plans are often tied to eligibility for Social Security. See, e.g., Music v. Western Conference of Teachers Pension Trust Fund, 712 F.2d 413, 415-16 (9th Cir. 1983) (eligibility for Teamster pension plan contingent on receipt of Social Security disability benefits). Therefore, a denial of Social Security benefits will leave even relatively well-protected workers without any source of income when they are not able to work due to a disability.

56. In some states, those found not to be disabled are ineligible for any public assistance or Medicaid coverage, regardless of their indigency. Many states have extremely limited public assistance programs for adults. See, e.g., Price v. Cohen, 715 F.2d 87, 89-90 (3d Cir. 1983) (discussing Pennsylvania's general assistance program). Even in states that have a public assistance program for indigent adults, there is no requirement that Medicaid coverage be provided to adults whose income is slightly over the public assistance standards and who have not yet been found to meet the disability criteria of the Social Security Administration. See Fullington v. Shea, 320 F. Supp. 500 (D. Colo. 1970), affd, 404 U.S. 963 (1971).

57. See Hyatt v. Heckler, 579 F. Supp. 985, 989-90 (D.N.C. 1984) (unable to afford adequate diet), vacated on other grounds, 757 F.2d 1455 (4th Cir. 1985), vacated, 476 U.S. 1167 (1986), affd in part, 807 F.2d 376 (4th Cir. 1986), cert. denied, 484 U.S. 820 (1987).

58. See, e.g., Holden v. Heckler, 584 F. Supp. 463, 478 (N.D. Ohio 1984) (forced to sell home to meet living expenses); Hyatt, 579 F. Supp. at 989 (forced to sell home because of inability to meet mortgage payments).

59. See Polaski v. Heckler, 585 F. Supp. 1004, 1013 (D. Minn.) (plaintiffs lose medical insurance when denied benefits), modified, 739 F.2d 1320 (8th Cir. 1984), vacated, 476 U.S. 1167, reinstated, 804 F.2d 456 (8th Cir. 1986), cert. denied, 484 U.S. 927 (1987); Holden, at 476 (unable to pay for recommended medical tests); Hyatt, 579 F. Supp. at 991 (termination of benefits "has often resulted in the inability of these persons to secure proper medical treatment for the very conditions from which they are disabled").

60. See Lopez v. Heckler, 725 F.2d 1489, 1497 (9th Gir.) ("[T]he district court has found that some class members have already died or suffered further illness as a result of the Secretary's actions. We agree with that finding."), vacated and remanded on other grounds, 469 U.S. 1082 (1984); Polaski, 585 F. Supp. at 1013 (claimants "die from the very disabilities the agency denies they have"); Hyatt, 579 F. Supp. at 992 ("On several known occasions, former recipients have died ... from the very conditions which SSA determined were not disabling severe impairments.").

Other claimants suffer a deterioration in their medical conditions. Stieberger v. Heckler, $615 \mathrm{~F}$. Supp. 1315, 1342 (S.D.N.Y. 1985) ("protracting the adjudicatory process by requiring claimants to pursue potentially futile procedures is frequently therapeutically detrimental to a claimant's mental and physical condition"), vacated on other grounds, 801 F.2d 29 (2d Cir. 1986); Thomas v. Heckler, 598 F. Supp. 492, 497 (M.D. Ala. 1984) (many claimants whose benefits are terminated suffer from "a substantial decline in health"); Polaski, 585 F. Supp. at 1013 (claimants who lose or are denied benefits "become increasingly anxious, depressed, despairing-all of which aggravates their medical conditions"); Holden, 584 F. Supp. at 478-79 (termination of benefits was a "significant cause of [the claimant's] worsened medical condition"); Hyatt, 579 F. Supp. at 992 (emotional stress from financial pressures "tends only to aggravate the severity of ... physical or emotional disabilities").

61. Estreicher \& Revesz, supra note $\#$, at 718. 
a full remedy. Although these hardships are less dramatic, they remain a cost to be factored into any cost-benefit analysis of nonacquiescence.

The final factor Estreicher and Revesz consider is the impact that nonacquiescence has on the workload of the Federal courts. Although they recognize that it is "logical to expect" with nonacquiescence, they do not discuss the magnitude of the burden their proposal places on the courts. If all disappointed parties before the agencies pursued their rights, the courts would be crushed by the burden of adjudicating repetitive identical cases. ${ }^{63}$ In the Social Security context, for example, the rate of judicial filings soared following the agency's adoption of a policy of nonacquiescence, leading to a significant impact on the judicial docket. ${ }^{64}$ Because it would bar judicial injunctions to require agencies to comply with circuit law, Estreicher and Revesz' proposal would have an even greater impact on the judicial workload. ${ }^{85}$ This judicial burden would only be mitigated to the extent that claimants were unaware of their likelihood of success on appeal.

A fair consideration of the costs and supposed benefits of nonacquiescence requires rejection of Estreicher and Revesz' proposed standard. Each benefit they identify is based on a view of the judicial system that does not square with the rules applied by the circuit courts. In contrast to the illusory benefits of nonacquiescence, its costs are undeniable. ${ }^{66}$

62. Id. at 750 .

63. Each case requires careful judicial review, even though the reversible error caused by nonacquiescence may appear to be easy to identify. Judicial review of administrative decisions generally calls on the court to reverse, affirm, modify, or remand. Because remand is a remedy that imposes additional delay on the party affected by nonacquiescence, a court may well feel an obligation to review the record to determine whether the administrative decision should be reversed. See, e.g., Carroll v. Secretary of HHS, 705 F.2d 638, 644 (2d Cir. 1983) ("A remand, potentially followed by another appeal, could well delay the payment of benefits to which Carroll appears to be entitled for still further years."). Such review is more burdensome and time consuming than reviewing a record where the proper legal standards have been applied and the court need only assess whether there is substantial evidence or an abuse of discretion. Furthermore, if circuit courts are to give consideration to abandoning past precedent, these cases could absorb the time of the entire circuit.

64. In fiscal year 1980, district courts issued dispositions in 8,179 appeals from denials of benefits. See Office of Hearings and Appeals, SSA, Operational Report $35-36$ (Sept. 1985) (4,859 affirmations, reversals, and dismissals, and 3,320 remands). By fiscal year 1985, the number of dispositions had increased to 27,858 with more than 50,000 cases pending. OfFice of Policy aNd Procedures, SSA, Court Remands: ANalysis and Recommendations 4 (Dec. 1987).

65. Injunctions against SSA have obviated judicial review of thousands of individual decisions. See, e.g., Hyatt v. Heckler, 711 F. Supp. 837, 843-48 (W.D.N.C. 1989); Thomas v. Heckler, 598 F. Supp. 492 (M.D. Ala. 1984); Mental Health Ass'n of Minn. v. Schweiker, 554 F. Supp. 157 (D. Minn. 1982), affd, 720 F.2d 965 (8th Cir. 1983).

66. Even if one accords weight to the benefits Estreicher and Revesz ascribe to nonacquiescence, the cost-benefit calculus should be tailored to the nature of the interest adjudicated by the agency. Where the agency administers a public benefits program, delay in the application of circuit law will have the most extreme costs, and the agency is most likely to be influenced by the cold calculus that affected parties will lack the resources to appeal. As discussed below, see infra p. 826, these considerations are directly relevant to due process balancing. Estreicher and Revesz provide little explanation for why they would permit intracircuit nonacquiescence in these circumstances, where the entire purpose of a congressional program-to provide monthly income or medical treatment-is frustrated by requiring parties to wait years to obtain their benefits. 


\section{Nonacquiescence and Chevron Deference}

In light of the disruption and unfairness caused by nonacquiescence, it is difficult to believe that Congress would choose to impose such disarray on the legal system. Estreicher and Revesz argue, however, that such express congressional authorization is irrelevant to the legality of nonacquiescence because a tolerance for nonacquiescence is implicit in "our administrative lawmaking system . . ." ${ }^{187}$ In particular, they argue that administrative agencies have statutory responsibilities to administer the law in a uniform manner. Thus, they suggest that in the absence of a specific congressional statement on the subject of nonacquiescence, a direction to apply the law uniformly should be treated as an interstice in a statute that agencies can interpret to include the authority to nonacquiesce. Once an agency reads such authority into the statute, Estreicher and Revesz would defer to the agency's reading, so long as nonacquiescence is constrained by their standards of reasonableness.

The principal authority Estreicher and Revesz rely on for this broad delegation to agencies is Chevron v. NRDC. ${ }^{88}$ They argue that Chevron recognizes that agencies play a special role in interpreting statutes and that an agency interpretation can only be struck down where it is inconsistent with clear congressional intent. ${ }^{6 \theta}$ The respect for agency interpretations of statutes set forth in Cheoron, however, does not address the question posed by nonacquiescence-namely the agency's authority to limit the effect of judicial decisions finding that the agency acted in violation of congressional intent.

Statutory obligations to apply the law uniformly cannot fairly be read as granting agencies the authority to choose whether to nonacquiesce. As explained above, nonacquiescence does not further uniformity in our existing system of judicial review. Although an illusion of uniformity may be created where affected parties do not seek judicial review, nonacquiescence in fact promotes disuniformity between those who appeal and those who do not. Any contribution to long-run uniformity, through circuits abandoning their precedents, is highly speculative.

More generally, nonacquiescence does not fit comfortably into the reasons for delegating the interpretation of statutory silence to agencies. The deference owed to agency interpretations of broad grants of authority is premised on the agency having special expertise and competence to decide the matter at issue. Where there is a broad grant of authority to make rules, it does not matter that Congress has not authorized a particular rule. The agency is trusted to exercise its expertise fairly to achieve overall congressional objectives.

67. Estreicher \& Revesz, supra note + , at 729 .

68. 467 U.S. 837 (1984).

69. Estreicher \& Revesz, supra note $\dagger$, at $724,729$. 
There is no broad grant of authority to agencies, however, to determine the scope of judicial review to supervise agency conduct. Judicial review of agency action, after all, is the principal means by which Congress can hope to hold agencies accountable to statutory limitations on agency power. $^{70}$ Thus, agencies do not enjoy the authority to determine when the courts have jurisdiction over agency action, ${ }^{71}$ whether the courts can issue class-wide injunctions, ${ }^{72}$ or other matters that bear on the scope of judicial review. Agencies are not entitled to deference on these issues because these matters do not fall within the agency's area of expertise, but rather concern the authority and effectiveness of the branch in charge of supervising and controlling agency excesses. ${ }^{73}$

The very factors identified by Estreicher and Revesz as relevant to the justifiability of nonacquiescence illustrate why the authoritative force of judicial decisions does not fit within the scope of matters properly delegated to an agency. For example, the burden of requiring the judicial branch to revisit issues that are settled within the circuit is not a matter that falls within the agency's special expertise. Similarly, the agency's position as a litigant is likely to influence its perspective on the burden that noncompliance with the law of the circuit imposes on affected parties. ${ }^{74}$ In addition to lacking expertise as to the concerns raised by nonacquiescence, an agency may have many interests implicated by nonacquiescence that have little to do with the factors identified as justifying nonacquiescence. For example, the agency may face budget pressures that would be eased by nonacquiescence. The agency may disagree with the policies mandated by statute and may wish to have the power to enforce its own view of the law. The agency may wish to stave off lawsuits for prospective injunctive

70. Indeed, some recent congressional initiatives have been directed towards expanding, rather than contracting, congressional control over agencies. See Sunstein, Participation, Public Law, and Venue Reform, 49 U. CHI. L. REV. 976, 976-77 (1982). Some of these efforts at control have been held to be invalid. See INS v. Chadha, 462 U.S. 919,966 (1983) (invalidating legislative veto). Judicial review remains one of the few ways that Congress can ensure that agencies do not exceed intended limitations.

71. The jurisdiction to determine jurisdiction is firmly placed with the judiciary. See generally Sager, The Supreme Court, 1981 Term-Foreword: Constitutional Limitations on Congress' Autharity to Regulate the Jurisdiction of the Federal Courts, 95 HARv. L. REv. 17, 26 (1981).

72. For example, the Supreme Court's decision that district courts can entertain class actions against SSA was not informed by the agency's claim that the statute should be read to require individual suits. See Califano v. Yamasaki, 442 U.S. 682 (1979).

73. In their Reply, Estreicher and Revesz note that deference to agencies is also based on the agency's appropriate institutional role as a policy-maker. Estreicher \& Revesz, Reply, supra note 18, at 841 . Grants of policymaking authority are subject to the constraints of judicial review. The balance between the judiciary's role in effectuating congressional intent and the agency's policy-making discretion is properly addressed in substantive standards for review of agency action, such as the standard set forth in Chevron. Nonacquiescence upsets this balance by allowing agencies to pursue their policies irrespective of judicial findings of invalidity made pursuant to these substantive standards.

74. For example, if SSA had been asked to weigh hardships before nonacquiescing in circuit standards for terminating benefits, it no doubt would have underestimated the hardships caused by its position. In the agency's view, these claimants had been properly terminated from benefits and were no longer disabled. See infra pp. 826-28 (discussing nonacquiescence in standard for terminating benefits). 
relief by relying on the added argument that the court is without power to issue injunctive relief because of a nonacquiescence ruling on the issue. ${ }^{75}$

The authority to nonacquiesce may also assist the agency in controlling the facts of cases that ultimately reach the Supreme Court by allowing the government to shop around for the most favorable set of facts for Supreme Gourt review. ${ }^{78}$

Most troubling is the fact that illegitimate considerations are likely to affect decisions to nonacquiesce. For example, agencies are most likely to nonacquiesce when they will not be burdened by high costs of litigation and readjudication at the agency level. Thus, they are most likely to read their statutes as permitting nonacquiescence when they can count on affected parties lacking the resources or the sophistication to appeal, or when the amount at stake for the affected party does not warrant the costs of seeking judicial review. The high likelihood that these factors will influence agencies makes nonacquiescence totally unsuited to treatment as a matter that falls within broad grants of delegated authority.

Estreicher and Revesz argue that such motives for nonacquiescence should not be imputed to agencies because agencies are entitled to a "presumption of regularity." "In In particular, they argue that there is no basis for assuming that a benefits agency charged with administering a program would seek to limit payments under the program. This argument is undoubtedly correct as a matter of administrative law when the agency is exercising its delegated authority. But the agency has no delegated authority to determine the scope of judicial power. Furthermore, the presumption of regularity loses its force when a court of appeals has concluded that the agency has acted outside the bounds of its discretion. Once the court has found that the agency has acted outside its authority, there is good reason to be concerned that the agency is not acting to effectuate the will of Congress but is instead swayed by extra-statutory concerns.

Viewing nonacquiescence as a delegated matter of statutory interpretation ignores the role that the courts play in effectuating congressional in-

75. Under Estreicher and Revesz' model, the power of nonacquiescence decisions to defeat litigation seeking injunctive relief would assure that many such decisions would be made during the course of litigation. It is common for agencies facing injunctive relief to attempt to avoid such relief. See, e.g., Hyatt v. Heckler, 711 F. Supp. 837, 840-41 (W.D.N.C. 1989); Dixon v. Bowen, 673 F. Supp. 123, 125-26 (S.D.N.Y. 1987); Stieberger v. Heckler, 615 F. Supp. 1315, 1367-76 (S.D.N.Y. 1985), vacated on other grounds, 801 F.2d 29 (2d Cir. 1986). Under current law, courts do not accord any presumption of regularity to attempts to defeat actions for injunctions "by protestations of repentance and reform." United States v. W.T. Grant Co., 345 U.S. 629, 632 n.5 (1953) (quoting United States v. Oregon Medical Soc'y, 343 U.S. 326, 333 (1952)). Instead, such efforts are closely scrutinized and viewed with suspicion. See id.; Ahrens v. Bowen, 852 F.2d 49, 52-53 (2d Cir. 1988).

76. The Solicitor General already has an advantage over other litigants in determining what cases are taken by the Court. See S. Estreicher \& J. SEXTON, supra note 25, at 100. Although Estreicher and Revesz do not treat the Solicitor General's failure to seek certiorari due to the facts of a case as fitting within their concept of reasonable efforts to obtain review, there is little way to police a standard that does not squarely require that certiorari be sought.

77. Estreicher \& Revesz, supra note + , at 757 n.346. 
tent. Indeed, Cheuron, the primary authority Estreicher and Revesz cite for the proposition that nonacquiescence falls within the scope of delegated discretion, reaffirms that the judiciary is the ultimate arbiter of the meaning of statutes. ${ }^{78}$ Although Cheuron requires that the courts defer to an administrative agency's construction of its governing statute, it leaves the courts with the final word whether the agency has complied with its statutory mandate.

Estreicher and Revesz essentially allow the agencies to double dip on their Cheuron rights to deference. They provide that even after a court has granted an agency the deference owed under Cheoron, it must further stay its hand in enjoining what the court has found to be an unwarranted exercise of agency power. Rather than counseling in favor of nonacquiescence, the deferential standard of review in Cheuron argues for increased enforcement of judicial declarations that agencies have acted outside the bounds of their authority. ${ }^{29}$

\section{The Constitutionality of Nonacquiescence Under The Existing Structure for Judicial Review of Agency Action}

Estreicher and Revesz analyze the constitutionality of nonacquiescence by postulating the existence of a statute explicitly authorizing such conduct by Federal agencies. They conclude that this hypothetical statute would pass constitutional muster. Regardless of whether one accepts the legality of such a statute, this analysis sheds little light on the constitutionality of nonacquiescence in the absence of such express congressional authorization. As explained above, because nonacquiescence implicates the

78. Chevron, 467 U.S. at 842-43 \& n.9; see INS v. Cardoza-Fonseca, 480 U.S. 421,447 (1987); Addison v. Holly Hill Fruit Prods., 322 U.S. 607, 616 (1944) ("determination of the extent of authority given to a delegated agency by Congress is not left for the decision of him in whom authority is vested").

79. See Strauss, supra note 29, at 1122 ("While nonacquiescence may have some intuitive force for an agency faced with a court decision that it is wrong under a precise decision model, it seems far less acceptable if a court has found an agency's interpretation to be beyond the zone of reasonableness.").

In their Reply, Estreicher and Revesz claim that we adopt an implicit view of agencies as identical to district courts. Estreicher \& Revesz, Reply, supra note 18, at 839-41. We recognize, however, that judicial review of agency action differs from appellate review of lower courts. For example, the deferential standard set forth in Chevron circumscribes judicial review of agency interpretation of statutes. In contrast, appellate courts exercise de novo review of district court decisions on statutory interpretation. Similarly, the appellate courts have far more power to structure proceedings in the district courts than before agencies. Compare Thomas v. Arn, 474 U.S. 140, 146-47 (1985) (circuit courts have supervisory authority to require parties to file objections to magistrates' reports) and New York State Ass'n for Retarded Children, Inc. v. Carey, 711 F.2d 1136, 1147 (2d Cir. 1983) (setting prudential rules for attorney fee records) with Vermont Yankee Nuclear Power Corp. v. NRDC, 435 U.S. 519 , 524 (1978) (courts cannot impose procedural requirements on agencies for rulemaking not mandated by statute) and FCC v. Pottsville Broadcasting Co., 309 U.S. 134 (1940) (on remand, agency must correct legal error identified by court, but may exercise its delegated discretion as to other matters). However, once a court of appeals, applying principles of judicial review of agency action, finds an agency to have exceeded the bounds of its delegated authority, the court's responsibility to effectuate the will of Congress becomes preeminent. 
scope and efficacy of judicial review, it cannot be assumed that Congress has delegated the matter to agencies through general grants of rulemaking or other quasi-legislative authority. Accordingly, the fact that Congress may be able to fashion a scheme of judicial review that permits nonacquiescence does not further the analysis of whether agencies can nonacquiesce given the existing structure of judicial review.

Without the benefit of express congressional guidance on the issue, assessment of the constitutionality of nonacquiescence calls for closer examination of the role of Article III courts in resolving disputes and declaring the law. Estreicher and Revesz accept the premise that the highest Article III court, the Supreme Court, issues declarations of law binding on the executive department through precedential effect. Marbury $v$. Madison ${ }^{80}$ settled the proposition that the judiciary can issue statements of law that bind officials of the other branches. In Cooper $v$. Aaron, ${ }^{\mathbf{8 1}}$ the Court held that its declarations of law are binding on governmental officials sworn to uphold the law, even though they may not have been formal parties to the case and were not bound by the terms of a court order ${ }^{82}$ Read together, Marbury and Cooper articulate a system of judicial review under which the judiciary does not simply issue narrowly framed orders which bind the parties to a case, but also announces declarations of law binding on the executive branch through precedential effect.

Under the Constitution, the power to issue binding declarations of law is an attribute of the judicial branch in general, not simply of the Supreme Court. Accordingly, the seminal Supreme Court decisions pertaining to separation of powers are framed as discussions of the authority of the judicial department as a whole. ${ }^{83}$ The issue, therefore, is where this power is situated within that branch.

This question can only be answered by looking to the structure of the judiciary and the system of judicial review created by Congress and the courts. The rules of appellate procedure and contours of stare decisis discussed in Part I reveal that the system delegates the power to create bind-

80. 5 U.S. (1 Cranch) 137 (1803).

81. 358 U.S. 1 (1958).

82. By its terms, Cooper dealt with the obligation of state and local officials to adhere to pronouncements of the judiciary. While some have argued that Cooper is inapplicable to Federal officials because the executive branch is a "co-equal" of the judiciary, see Meese, The Law of the Constitution, 61 Tul. L. Rev. 979, 986-88 (1987), we agree with Estreicher and Revesz that such a distinction is unsupportable. In United States v. Nixon, 418 U.S. 683, 704 (1974), the Court rejected the notion that the executive branch is a "co-equal" to the judiciary in matters of interpretation of law. See also INS v. Cardoza-Fonseca, 480 U.S. 421,447 (1987) ("[t]he judiciary is the final authority on issues of statutory construction") (quoting Chevron U.S.A., Inc. v. NRDG, 467 U.S. $837-43$ n.9 (1984)). Indeed, Cooper is far more sweeping in its assertion of the obligation to follow declarations of law since it applies to non-parties to the proceeding that created the precedent. See supra note 28.

83. See United States v. Nixon, 418 U.S. at 704 (judicial power of the United States vested in the Federal courts by Article III $\S 1$ ); Cooper, 358 U.S. at 18 ("[T]he federal judiciary is supreme in the exposition of the law of the Constitution"); Marbury, 5 U.S. at 177 ("It is, emphatically, the province of the judicial department, to say what the law is."). 
ing precedent within each region to the courts of appeals. ${ }^{84}$ In this way Congress and the courts have sacrificed precise uniformity across regions in favor of a system that produces a unitary rule of law in each region in a timely manner. Absent such a system, there would be little left of the Article III function of issuing binding declarations of law. Such declarations could be issued solely by the Supreme Court, or following years of litigation in the circuit courts, and would therefore be unavailable as a practical matter. In effect, the judiciary would be stymied by its sheer size and would be unable to generate rules of conduct for long periods of time. Although the judicial system does not make declarations of law issued by courts of appeals immutable and has mechanisms for resolving regional conflicts, the rules constraining reconsideration of precedent make the declarations of law by circuit courts binding statements within their jurisdictions unless and until they are overturned.

In contrast, Estreicher and Revesz' proposal renders the decision of a circuit court little more than a vote to be counted in a later determination of what the law should be. While their proposal would minimize the possibility that agencies would act in reliance on declarations that are subject to change, it would greatly reduce the power of the judicial branch to issue binding statements of law. It would also create an anomalous situation where the accepted rules of agency conduct would conflict with the rules available to parties in court. The judiciary's role as resolver of individual disputes would be severed from its function as declarer of the law, thereby undermining the system of voluntary compliance that society relies on to resolve most disputes without resort to the judiciary. ${ }^{85}$ Above all, the system they propose is not the model that Congress and the courts have adopted. ${ }^{86}$

Estreicher and Revesz argue that their model leaves the formal authority of the courts of appeals unimpaired. ${ }^{87}$ But in fact, their proposal greatly limits the powers of these courts. Most importantly, their model makes it impossible for any court to issue injunctive relief until a consensus has emerged in the circuits, or the Supreme Court has spoken on an issue. In fact, Estreicher and Revesz recognize that the power of the lower courts to enjoin agency action is at odds with their proposal that agencies remain free to engage in nonacquiescence until the judicial system as a

84. See supra pp. 803-11.

85. See Neuborne, The Binding Quality of Supreme Court Precedent, 61 TuL. L. REv. 991, 994-95 (1987).

86. In a recent article, Professor Joshua Schwartz raises new questions about the compatibility of intracircuit nonacquiescence and Article III. See Schwartz, supra note 28. Professor Schwartz argues that agencies engaged in adjudication are exercising Article III power, and are therefore bound by the precedential rules of Article III courts. Professor Schwartz' analysis is rooted in a constitutional right to judicial review of agency fact finding. Our analysis applies wherever Congress has granted a right to judicial review.

87. Estreicher \& Revesz, supra note 7 , at 731. 
whole has reached a final resolution of a matter. ${ }^{88}$ But they fail to recognize that these existing remedial powers are a further indication that nonacquiescence conflicts with the powers Congress has vested in the lower Federal courts.

The degree to which Estreicher and Revesz' proposal conflicts with the current availability of judicial relief reveals the radical nature of nonacquiescence. Their prohibition on prospective injunctions until the judiciary as a whole has resolved an issue would dramatically undermine the potency of judicial review and thereby diminish the ability of the courts to require agency adherence to congressional standards.

A different question would be presented were Congress to choose to restructure the powers of the lower courts through limitations on injunctive powers, revision of the rules regarding precedent, or a specific authorization of nonacquiescence. Similarly, limitations on judicial review for specific programs may indicate a congressional preference for a less vigorous role for the lower courts than that suggested by the general structure of the lower courts. For example, Congress has expressly withheld traditional injunctive powers from the judiciary in cases challenging the collection of taxes. ${ }^{89}$ But absent a strong congressional limitation on traditional judicial powers, the existing structure of judicial review requires that the decisions of the circuit courts be treated as authoritative. ${ }^{90}$ Before conclud-

88. The power of lower Federal courts to enjoin agency conduct is firmly established in the Federal Rules of Civil Procedure. Far from requiring definitive resolution of an issue by the entire judicial branch, Rule 23 allows a district court to certify a plaintiff class and enter a class-wide preliminary injunction against an agency under Rule 65 , based solely upon its own weighing of the equities and a finding that a class of plaintiffs has shown a "likelihood of success on the merits" or has presented "sufficiently serious questions going to the merits to make them a fair ground for litigation." Ellender v. Schweiker, 550 F. Supp. 1348, 1357 (S.D.N.Y. 1982) (quoting Jackson Dairy, Inc. v. H.P. Hood \& Sons, Inc., 596 F.2d 70, 72 (2d Cir. 1979) (per curiam)); see Leschniok v. Heckler, 713 F.2d 520, 524 (9th Cir. 1983); Lyon v. Weinberger, 376 F. Supp. 248 257-63 (S.D.N.Y. 1974). Upon losing in district court, an agency can appeal but is not entitled to an automatic stay of the lower court's order. Instead, Federal agencies must satisfy the same discretionary standards for stays pending appeal as other litigants. See FED. R. Crv. P. 62(c); FED. R. APp. P. 8. See, e.g., Mental Health Ass'n of Minn. v. Heckler, 720 F.2d 965, 967 n.5 (8th Cir. 1983). These rules enable the judicial branch to respond quickly to challenges to agency action.

89. 26 U.S.C. $\$ 7421$ (1983).

90. In some instances, statutory schemes may provide for particularly potent judicial review which renders nonacquiescence especially offensive to principles of the separation of powers. For example, determinations of SSA are subject to a system of judicial review that "suggest[s] a degree of direct interaction between a federal court and an administrative agency alien to traditional review of agency action under the Administrative Procedure Act." Sullivan v. Hudson, 109 S. Ct. 2248, 2254 (1989).

In their Reply, Estreicher and Revesz suggest that Congress has approved of nonacquiescence by failing to outlaw it in the Social Security Disability Reform Act of 1984. Estreicher \& Revesz, Reply, supra note 18 , at 844 . This reading of the legislative history is unwarranted, since the Conference Committee expressly stated that its failure to reach agreement on a specific provision banning nonacquiescence should not be construed as an endorsement of nonacquiescence. H.R. CONF. REP. No. 1039, 98th Cong., 2d Sess. 37, reprinted in 1984 U.S. Code Cong. \& Admin. News 3095; see Stieberger v. Heckler, 615 F. Supp. 1315, 1361-62 (S.D.N.Y. 1985), vacated on other grounds, 801 F.2d 29 (2d Cir. 1986). 
ing that Congress has decided to curtail the judicial functions of Article III courts, a clear statement of such an intent should be required. ${ }^{91}$

Entirely apart from separation of powers objections, nonacquiescence poses serious equal protection and due process concerns. Estreicher and Revesz correctly recognize that due process and equal protection analyses of nonacquiescence depend on the particular administrative program involved. ${ }^{92}$ They nonetheless conclude that it is always permissible for an agency to nonacquiesce for a period of time. ${ }^{93}$ This per se rule does not accord with constitutional standards that are sensitive to indigency and hardship.

Estreicher and Revesz argue that disparities between those parties who cannot appeal to court and those who can is analogous to the imposition of fees as a prerequisite to filing a lawsuit. Stated in its strongest form, the analogy suggests that many disparities in society render some parties better able to pursue litigation than others and that the judicial system need not be structured to equalize all of these distinctions. As Estreicher and Revesz explain, the Supreme Court has upheld statutory provisions that limit access to the courts, including the imposition of a reasonable filing fee on bankruptcy petitions, ${ }^{94}$ and fees to commence litigation challenging administrative proceedings. ${ }^{95}$

The reasoning of these cases limiting the principle of litigant equality does not extend to situations where the government itself is applying different legal rules based on an individual's ability to pursue judicial remedies. ${ }^{96}$ When an agency nonacquiesces, cases are decided under two sets of standards. One set applies to those who do not appeal. Another applies to those who appeal and have their cases remanded for application of binding circuit law. The choice of standards depends entirely on the affected party's ability to navigate the system of administrative and judicial appeals. Rather than endorsing the use of such disparate standards, the reasoning of the Court's opinion in Ortwein v. Schwab, which upholds filing fees to challenge administrative proceedings, casts serious doubt on the permissibility of basing agency adjudicatory standards on the ability to pay a fee. In Ortwein, the Court noted that there was no reason to doubt

91. In Califano v. Yamasaki, 442 U.S. 682 (1979), the Court declined to infer a limitation on the power of the judiciary to issue injunctive relief or to certify plaintiff classes absent a clear statement of such an intent from Congress. A clear statement rule is plainly appropriate with respect to nonacquienscene in light of the effect of nonacquiescence on the power of the judicial branch. As explained above, administrative agencies are particularly unsuited to evaluate the issues raised by nonacquiescence. See generally Hampton v. Mow Sun Wong, 426 U.S. 88 (1976) (clear statement from Congress required where issues at stake went beyond those properly of concern to agency).

92. Estreicher \& Revesz, supra note $\dagger$, at 732-35.

93. According to Estreicher and Revesz, fairness concerns should only affect the degree to which consensus of other circuit courts is necessary before nonacquiescence must be halted. Id. at 757 .

94. United States v. Kras, 409 U.S. 434 (1973).

95. Ortwein v. Schwab, 410 U.S. 656 (1973) (per curiam).

96. In general, these cases stand for the proposition that a judicial system may impose reasonable fees to pay for its administration. Ortwein, 410 U.S. at 660; Kras, 409 U.S. at 447-49. 
that the administrative proceedings had been conducted fairly. ${ }^{97}$ Thus it granted the agency a presumption of regularity that rendered judicial review less important. Far from assuring that the administrative process acts with regularity, nonacquiescence means that the administrative process virtually guarantees reversible error. ${ }^{98}$

For agencies that conduct adjudicatory proceedings, deliberate reliance on legal standards rejected by reviewing courts raises serious due process questions. Rather than providing a means for fairly determining the rights and obligations of parties, the administrative process becomes a series of obstacles yielding decisions that are predictably subject to reversal by reviewing courts. ${ }^{98}$ It is hard to see how these burdensome procedures imposed by nonacquiescence can be justified by the tenuous governmental interests involved. ${ }^{100}$ Even if all parties appealed, the result would be to delay the application of judicial standards. This delay in itself can raise serious due process concerns. ${ }^{101}$

Application of Estreicher and Revesz' proposed test to the most notorious example of nonacquiescence in the 1980's, SSA's rejection of the "medical improvement" standard, illustrates how it would legitimate nonacquiescence that violates the constitutional rights of parties appearing before agencies as well as principles of separation of powers. ${ }^{102}$ Litigation concerning this issue also illustrates the central role that injunctive relief plays in curbing agency excesses.

SSA's formal ruling of nonacquiescence in Patti $v$. Schweiker ${ }^{\mathbf{1 0 3}}$ appears to satisfy the proposed "reasonableness" test. In Patti, the Ninth Circuit

97. 410 U.S. at 659 n.4. The Court noted that administrative hearings "provide a procedure, not conditioned on payment of any fee, through which appellants have been able to seek redress." Id. at 660 .

98. A number of courts have expressed doubts about the validity of such a system under due process and equal protection principles. See Lopez v. Heckler, 713 F.2d 1432, 1440 (9th Cir. 1983), adhered to, 725 F.2d 1489 (9th Cir.), vacated on other grounds, 469 U.S. 1082 (1984); Jones v. Califano, 576 F.2d 12, 20 (2d Cir. 1978); Stieberger, 615 F. Supp. at 1363.

99. Estreicher and Revesz argue that due process objections to nonacquiescence merely restate separation of powers arguments. Estreicher \& Revesz, supra note + , at 731-32. The issues, however, are distinct. Separation of powers analysis asks whether the structure of government requires the agency to apply the declarations of law of the circuit courts. Due process analysis inquires into the procedures followed to adjudicate cases and balances the relevant governmental and individual interests at stake. Under due process analysis, the likelihood that a set of procedures will alter the outcome of a case is highly relevant. Thus, the mere possibility that a circuit court would reverse settled precedent would rarely justify the cumbersome administrative and judicial procedures that nonacquiescence imposes on parties before the agency.

100. See supra pp. 812-17.

101. See Cleveland Bd. of Educ. v. Loudermill, 470 U.S. 532, 543 (1985); Barry v. Barchi, 443 U.S. 55, 66 (1979); Fusari v. Steinberg, 419 U.S. 379, 339 (1975).

102. A full discussion of this instance of nonacquiescence is found in S. MEZEY, No LoNGER Disabled: The Federal Courts and the Politics of Social Security Disability (1988). Although nonacquiescence in the medical improvement standard has received the most attention, SSA has failed to conform its administrative practices to comply with many circuit court decisions without formally announcing its nonacquiescence. See generally Kubitschek, supra note 53, at 443-49 (discussing SSA's nonacquiescence practices).

103. 669 F.2d 582 (9th Cir. 1982). 
held that the agency could not terminate payment of disability benefits on the ground that a recipient is no longer disabled, without first concluding that the individual's medical condition had improved since the last time the recipient had been found eligible. After the court's decision in Patti, the agency vigorously pursued the issue in other circuits. Although all circuits that considered the issue eventually ruled against the agency, ${ }^{104}$ it could not be said at the outset that SSA's litigation position was frivolous in circuits that had not yet ruled on the matter. ${ }^{105}$ Under Estreicher and Revesz' standard, nonacquiescence in Patti appears to have been "reasonable."

The consequences of the agency's refusal to follow Patti and similar cases in other circuits were catastrophic for hundreds of thousands of disabled persons. ${ }^{108}$ As discussed above, the hardships they were forced to endure included deprivations of basic necessities and essential medical care. ${ }^{107}$ When recipients appealed these determinations to court, they prevailed in the overwhelming majority of cases. ${ }^{108}$ Because of the disparity between administrative and judicial rules, the number of cases challenging the agency's denials of benefits filed in district courts increased dramatically. Between 1980 and 1985 the number of court dispositions of such cases trebled. ${ }^{100}$ Even so, thousands of disabled persons were unable to appeal to court.

Recipients who lost benefits filed class actions to halt SSA's nonacquiescence in the cases requiring application of a medical improvement standard. ${ }^{110}$ These class actions provided prospective relief that spared

104. Byron v. Heckler, 742 F.2d 1232 (10th Cir. 1984); Buckley v. Heckler, 739 F.2d 1047 (5th Cir. 1984); Rush v. Secretary of HHS, 738 F.2d 909 (8th Cir. 1984); DeLeon v. Secretary of HHS, 734 F.2d 930 (2d Cir. 1984); Haynes v. Secretary of HHS, 734 F.2d 284 (6th Cir. 1984); Dotson v. Schweiker, 719 F.2d 80 (4th Cir. 1983); Kuzmin v. Schweiker, 714 F.2d 1233 (3d Cir. 1983); Simpson v. Schweiker, 691 F.2d 966 (11th Cir. 1982). In addition, a number of circuits had rejected SSA's argument prior to Patti. See Cassiday v. Schweiker, 663 F.2d 745 (7th Gir. 1981); Miranda v. Secretary of HEW, 514 F.2d 996 (1st Cir. 1975). The Secretary did not seek certiorari immediately, and Estreicher and Revesz' proposal may not have required it to have done so. Estreicher \& Revesz, supra note + , at 756 ("it might be reasonable for the agency not to seek [Supreme Court] review in advance of an intercircuit conflict").

105. For example, the Second Circuit hesitated to adopt the medical improvement standard. See Delamater v. Schweiker, 721 F.2d 50 (2d Cir. 1983); see also Wheeler v. Heckler, 719 F.2d 595 (2d Cir. 1983) (declining to adopt medical improvement standard for Supplemental Security Income recipients grandfathered into program); Smith v. Schweiker, 709 F.2d 777 (2d Cir. 1983) (affirming on jurisdictional grounds dismissal of class action on merits challenging agency's failure to apply medical improvement standard).

106. Nationally, SSA terminated the benefits of approximately 500,000 recipients between March 1981 and April 1984. DeLeon v. Secretary of HHS, 734 F.2d 930, 931 n.1 (2d Cir. 1984).

107. See supra pp. 814-16.

108. In fact, by 1984, when many of these cases reached the judiciary, over $80 \%$ of the denials or terminations of benefits reviewed by courts were overturned. OfFICE of Policy and Procedures, supra note 64 , at 4 .

109. The number of court dispositions concerning the denial or termination of benefits rose from 8,179 to 27,858 during the course of five years. See supra note 64 .

110. See, e.g., Lopez v. Heckler, 713 F.2d 1432 (9th Cir. 1983), adhered to, 725 F.2d 1489 (9th Cir.), vacated on other grounds, 469 U.S. 1082 (1984); Polaski v. Heckler, 585 F. Supp. 1004, 1011-13 (D. Minn. 1984), remanded on other grounds, 751 F.2d 943 (8th Cir. 1984); Holden v. 
thousands of persons the hardship of losing their subsistence income pursuant to standards found invalid by their circuits' court of appeals. ${ }^{111}$ Most of these individuals would not have appealed and would not have received relief through individual actions. Under the Estreicher and Revesz proposal, the courts that certified these plaintiff classes and granted this relief acted wrongly. Instead, the proposal would have required these courts to forebear from granting relief until a consensus of the circuits solidified or the Supreme Court granted review. ${ }^{112}$

The confrontation between the judiciary and SSA created by the agency's nonacquiescence was ultimately resolved by congressional rejection of the agency's standard. ${ }^{113}$ Even despite eventual class action orders and congressional action, agency nonacquiescence seriously harmed tens of thousands of disabled persons. These recipients suffered years of interruption or permanent deprivation of benefits intended to provide a basic monthly income. This predictable and serious harm was inflicted for no discernible legitimate interest.

The medical improvement issue is unusual in that it affected hundreds of thousands of people in a short period of time. This sudden and massive effect brought about widespread publicity and relatively rapid resolution of the issue in the courts and by Congress. But even in this context, nonacquiescence allowed the agency to wreak havoc on the lives of those who relied on it to execute the law faithfully. In other contexts, where nonacquiescence continues through years of "percolation," the absence of Supreme Court or congressional intervention would allow equally serious harms to continue unabated.

\section{ConCLUSION}

Our system of judicial review of agency action depends upon oversight by the lower Federal courts. Through court of appeals' precedents and district court injunctions, the judiciary can respond quickly to challenges to agency action. Thus, a court of appeals decision creates binding precedent at the time it is issued and not simply at some later point when it is adopted by the other circuits or affirmed by the Supreme Court. Similarly, district court judges can issue injunctions based on their view of the law

Heckler, 584 F. Supp. 463 (N.D. Ohio 1984).

111. For example, class-wide preliminary injunctive relief was provided in Lopez v. Heckler, 713 F.2d at 1432. While the Supreme Court stayed the retroactive portion of the injunction pending appeal to the Ninth Circuit, the prospective relief granted by the district court remained in effect throughout the appellate proceedings. Heckler v. Lopez, 463 U.S. 1328 (Rehnquist, J., Circuit Justice) (granting partial stay), affd by full Court, 464 U.S. 879 (1983).

112. Adoption of Estreicher and Revesz' proposal might have allowed courts to issue injunctions at some point prior to consideration by all of the circuits. It would have insulated the agency from injunctive relief, however, until a number of circuits had considered the issue. Estreicher \& Revesz, supra note $H$, at 757.

113. Disability Reform Act of 1984, Pub. L. No. $98-460,98$ Stat. 1805 (codified at 42 U.S.C. $\S$ 423(f) (Supp. V 1987)). 
without waiting to poll the judiciary as a whole on an issue. This delegation of authority to the lower federal courts gives rise to a system in which court decisions that affect private individuals and administrative agencies are sometimes later rejected, either on direct appeal or through appeal of similar cases. But reliance on court decisions that may one day be overturned is inherent in a legal system designed to protect rights in a timely manner.

Estreicher and Revesz' proposal is particularly unfair because it would make standards enunciated by the lower Federal courts available to some parties, but not others. Under their proposal, an agency decision to nonacquiesce would prohibit the lower courts from requiring agencies to apply judicial standards in making initial decisions. Even the device of the class-wide injunction, designed to accord the benefits of judicial rules to those who would not otherwise have access to courts, would be unavailable. At the same time, the proposal would leave the lower courts free to order the agency to apply judicial standards to individual parties who file cases in court.

While we do not believe that effective judicial review should be rendered more remote in any respect, it is the partial nature of Estreicher and Revesz' proposal that renders it a pernicious system of judicial review. The elimination of disparities between the needy and the well-off may be a distant goal, but a system of judicial review that is founded on the ability of parties to purchase the rule of law is surely a step backwards. 


$$
\text { . }
$$

